\title{
カーボン膜の還元作用による中空マイクロナノ構造体の作製
}

\section{Fabrication of Micro and Nano Hollow Structures by Reductive Activity of Carbon Film}

\author{
○学 岡田 生（秋田大院）正村岡 幹夫（秋田大）
}

Sho OKADA, Graduate Student of Akita University, 1-1 Tegatagakuen-machi, Akita Mikio MURAOKA, Akita University, 1-1 Tegatagakuen-machi, Akita

Key Words : Material Process, Nanotube, Microtube, Carbon Film, Reduction, Multi-Walled Tube

\section{1. 緒言}

中空ナノ構造体は，優れた物理特性を有し，ガスや夜 体の流路, 燃料電池, センサへの応用が期待されている。 これまで, 中空ナノ構造体の作製手法としては, 化学気 相蒸着法（CVD）などの自己組織化, テンプレート法, 被覆ナノワイヤのコア部除去法が利用されている(1) (4) 自己組織化法による中空ナノ構造体の作製は, 自己組織 化を発現する材料が限られているため, 適用材料の種類 に限りがある。また, 偶発的要素のある自己組織化反応 によって作製されるため, 形状制御が困難な場合が多い. テンプレート法については, 型材除去の際に, 溶剂を使 用したウエットエッチング処理を伴うため, 簡便な方法 とは言い難い。さらにコア部除去法においては，ウエッ トエッチング, 酸化然焼, あるいは昇華によってコア部 を除去するが，酸化燃焼や昇華によるコア部除去には， 高温処理が必要となる。

本研究では, カーボン膜を被覆した金属酸化物微細材 料を還元させることにより，中空微細材料を作製する手 法を提案する。本手法は, 周囲に還元剂となるカーボン 膜を被覆した金属酸化物微細材料を鋳型として用い,さ らに外皮となる金属を被覆後, 不活性ガス中で加熱還元 することにより, 空洞を有する微細構造体を得るもので ある（図 1)。なお，本手法は，金属酸化物鋳型と金属 外皮の間に還元剂としてカーボン膜を挿入しているた め, 鋳型が金属外皮に内包され外気に触れない状態にお いても，低温にて $\left(300{ }^{\circ} \mathrm{C}\right.$ 以下）加熱のみで確実に鋳型 を還元除去することができる。

\section{2. 作 製 方 法}

本研究では, 酸化銅ナノワイヤ $(\mathrm{CuO} \mathrm{NW})$ を鋳型と して用いる。 $\mathrm{CuO} \mathrm{NW}$ は, 純度 $99.9 \%$ の銅細線（直径 $0.1 \mathrm{~mm}$ ) を大気中 $600{ }^{\circ} \mathrm{C} の$ 温度にて熱酸化することに

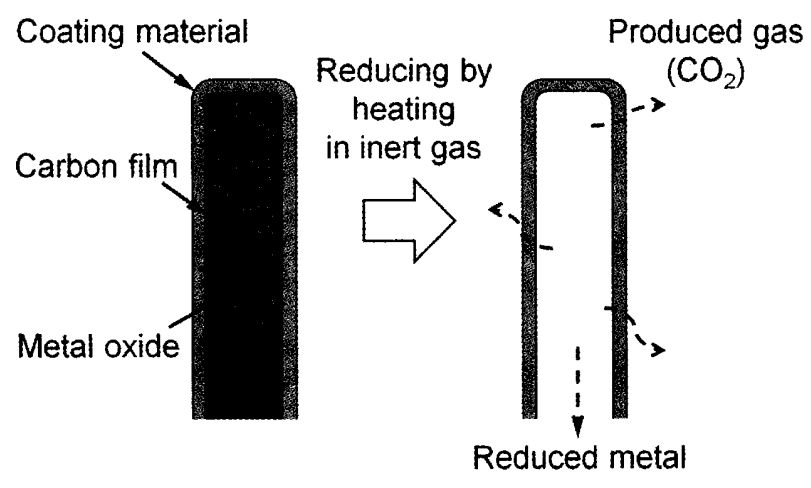

Fig. 1 Fabrication principle of hollow structure.
よって細線の表面上に生成する ${ }^{(5)}$. 加熱時間は 4〜40 時 間とし, 直径数 $10 \mathrm{~nm} \sim 700 \mathrm{~nm}$, 長さ数 $\mu \mathrm{m} \sim 100 \mu \mathrm{m}$ の $\mathrm{CuO} \mathrm{NW}$ 群を生成する.なお, 加熱時閒を長くするほど, NW の直径は大きなる。次に，図2(a)に示すように，多 自由度ナ八把持装置 ${ }^{(6)}$ 用いて, 単一の NW を分離し, さらに図 2(b)のように AFM カンチレバー先端に付着さ せる。続いて, NW 付着カンチレバーを, NWがターゲ ットと平行になるように, スパッタ装置に設置し, 還元 凨となるカーボン膜を被覆する.また, 周方向均一に被 覆をするため，NW が付着したカンチレバーを裏返し， 対称方向から再度被覆を施す. カーボン膜の被覆後, 同 様に白金（Pt）の被覆を行う. カーボン膜の膜厚および Pt の膜厚をそれぞれ $2 \mathrm{~nm}$, および $80 \mathrm{~nm}$ とする. 次に, 被覆した NW 付きカンチレバーを, $\mathrm{Ar}$ ガス中 $300{ }^{\circ} \mathrm{C} の$ 温度にて 30 分間加熱する.これにより, $\mathrm{CuO} \mathrm{NW}$ を還

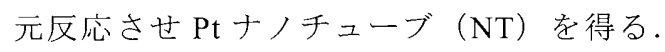

一方で, 外皮金属の被覆後, さらにカーボン膜, 外皮 金属を再被覆し, 加熱還元することにより多層チューブ の作製を行う。なお, 多層チューブの作製において, 本 手法の他材料への適用性を確認寸るために, 外皮金属と して銀 $(\mathrm{Ag})$ を使用する. カーボン膜および銀の膜厚 は, それぞれ 1 層当たり $60 \mathrm{~nm}, 100 \mathrm{~nm}$ とする。多層チ ューブ作製に拉いても同様に, $\mathrm{Ar}$ ガス中 $300{ }^{\circ} \mathrm{C}$ の温度 にて 30 分間加熱還元を行う.
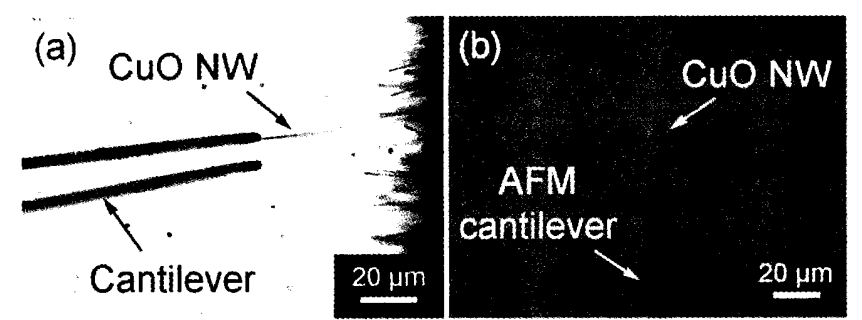

Fig. 2 (a) Separating a $\mathrm{CuO}$ NW. (b) AFM cantilever with the $\mathrm{CuO}$ NW.

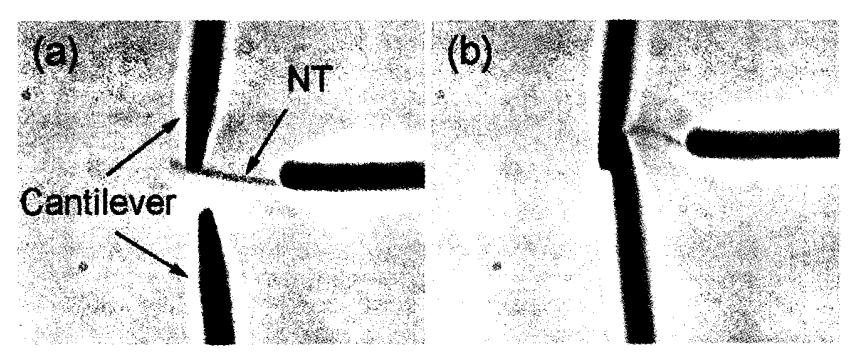

Fig. 3 (a) Before cutting an NT. (b) Just before bending fracture of the NT. 

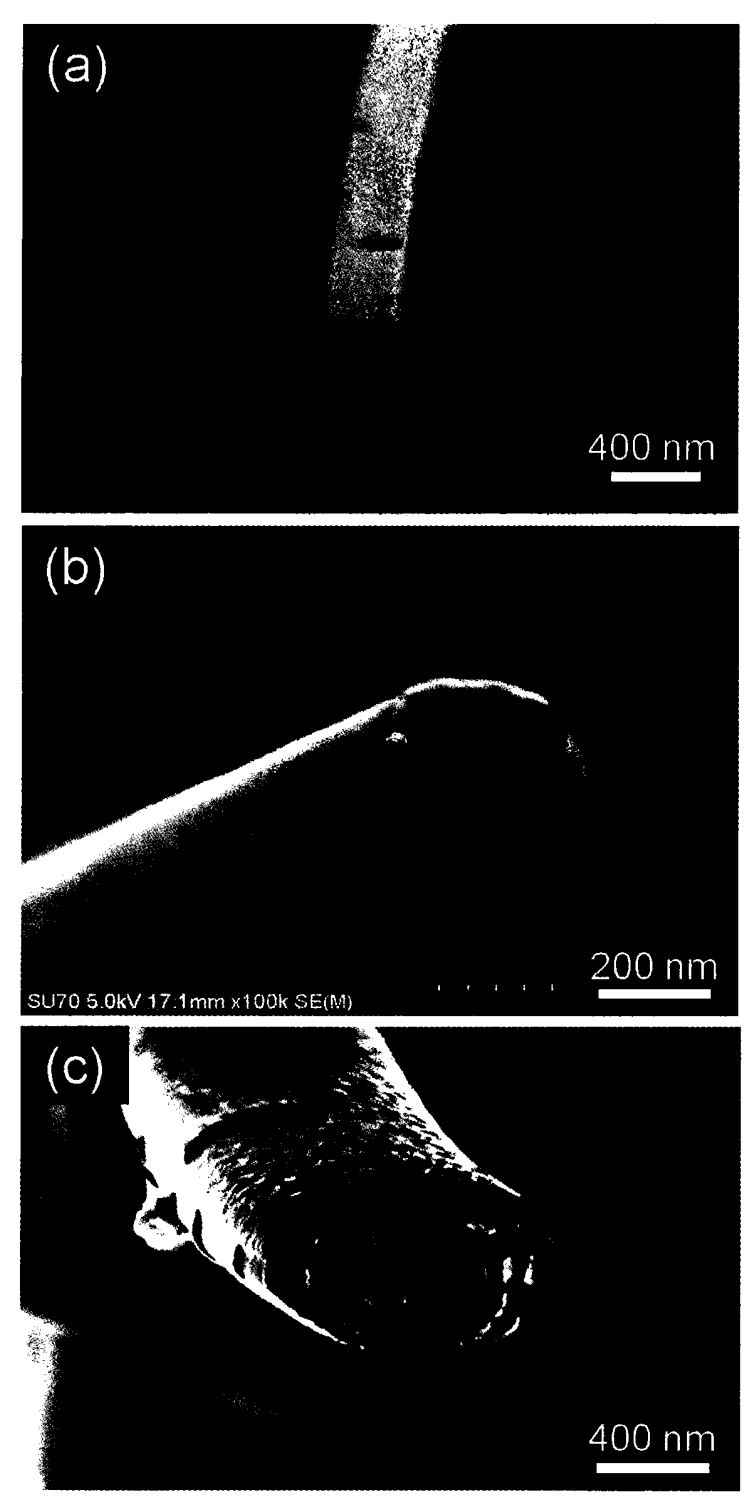

Fig. 4 FE-SEM images of NTs. (a) Before cutting a Pt NT. (b) After cutting a Pt NT. (c) A multi-walled Ag NT.

なお，作製したチューブの断面形状を観察するために， 図 3 に示すように, 多自由度ナノ把持装置を応用して NTの切断を行う.

\section{3. 結果および考察}

図 4 は, 本手法により作製した NT の電界放射型電子 顕微鏡（FE-SEM）像である.図 4(a)は単層白金 NT の 切断前の形状例である. チューブ直径は約 $300 \mathrm{~nm}$ とな っている．また，NT 先端が開口していないことがわか る. 図 4(b) は単層白金 NT の断面形状を示している.NT の外径は約 $300 \mathrm{~nm}$ である．チューブ断面形状から，空 洞を確認することができる。図 4(c), は, 多層銀 NT の 断面形状である。チューブ外径は，約 $800 \mathrm{~nm}$ であり， また, カーボン膜を被覆した箇所が空洞となっているの

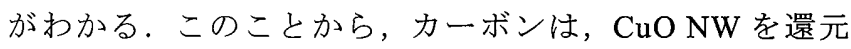
し二酸化炭素ガスとなり，あるいは，カーボン原子とし て外皮金属の結晶格子間, 粒界を通過し, 外部へ排出し たと考えられる。

図 5 に，作製した NTについてのエネルギー分散型 X
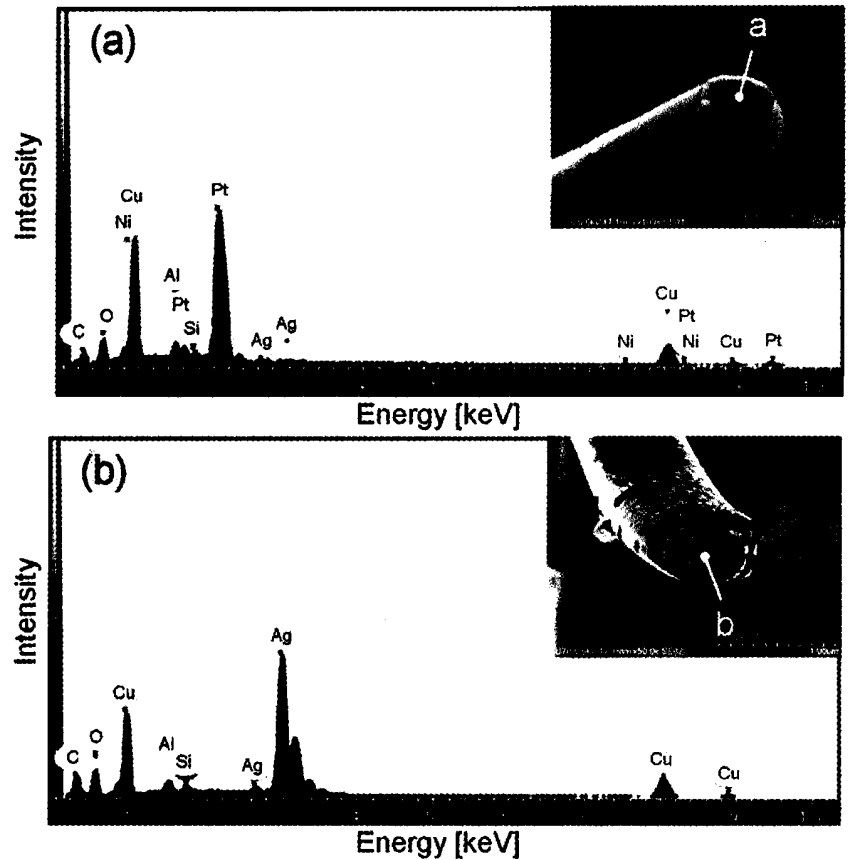

Fig. 5 EDX spectrums of the (a) Pt NT, and (b) multi-walled Ag NT.

線分析 (EDX) 結果を示す. 図 5(a) は，単層 NT の中心 部分, (b)は多層 NT の中心部分の分析結果である。(a), (b)の両方において, $\mathrm{Cu}$ および外皮金属（Pt， Ag）が顕 著に検出されている.また, 小さいがカーボンや酸素を 示すピークもみられる. 図 5(a)から, 単層 NTにおいて は，酸素を示すピークが比較的低く， $\mathrm{Cu}$ を示すピーク が大きいことから，ある程度還元ができたことがわかる。 また，還元により生成した $\mathrm{Cu}$ は，大気放出されず NT 内壁面に堆積していると考えられる.多層 NTについて は，図 5(b)に示すように，Cu に対する酸素のピークが 高いことから，還元時間が不十分であったと考えられる。

\section{5. 結言}

本研究では, 還元容易な金属酸化物ナノ材料を鋳型と して用い,これに還元剤となるカーボン膜を被覆した後, さらに外皮となる金属を被覆し, 不活性ガス中にて加熱 還元することにより, 空洞を有する微細構造体を作製す る手法を提案し，作製に成功した．また，カーボン膜お よび外皮金属を 2 重に被覆することにより，多層ナノチ ューブの作製が可能であることを示した.

\section{文献}

（1）田中 宏幸，マイクロ・ナノ構造体及びその製法，特 開 2008-94686, 2008.4.24.

(2) L. Li, Y. W. Yang, G. H. Li, and L. D. Zhang, Small, Vol. 2, (2006), pp. 548-553.

(3) M. S. Sander, Thermoelectric nanotube arrays, US Patent, US2007-0277866, 2007. 12. 6.

（4）曽志荏,ナノチューブ構造の製造方法, 特開 2011-36995, 2011.2.24.

(5) X. Jiang, T. Herricks, and Y. Xia, Nano Lett., Vol. 2, (2002), pp. 1333-1338.

(6) K. Kobayashi, Y. Toku, and M. Muraoka, Manipulation of Nanowires by Chopsticks, Proc. ATEM'11, (2011), p. 145. 